DOI https://doi.org/10.36059/978-966-397-105-6/25-45

\title{
HYDROPOWER AND WIND ENERGY
}

\author{
Kyselov V. B.
}

\section{Hydropower}

\subsection{General characteritics}

Hydropower is energy, concentrated in streams of water masses in river watercourses and tidal movements.

The hydropower plant operates on "free fuel": solar energy evaporates water (mainly from the surface of the oceans), air flows transfer steam to the continents, where it condenses and falls in the form of rain and snow. Moisture falling to the surface of the earth partially evaporates again, partially collects into rivers and flows back into the oceans. The river flow of Ukraine is $46 \mathrm{~km}^{3}$ water per year (about 20 thousand $\mathrm{m}^{3}$ per capita).

Hydropower plants mainly operate in the variable peak part of the load graph, and only while flood - in basic mode.

\subsection{Types of hydropower plant devices and hydro turbines}

They distinguish between derivative hydropower plants, the buildings of which are installed on the channel diverted from the reservoir (the upper buffer of the hydroelectric hub), and the dams, in which the hydro turbines and generators are placed directly in the dam. The low-pressure hydropower plants widely used in the northwest are of the crest type. Their structures typically include a soil barrier blocking the bed and a small concrete dam and the hydropower plant building adjacent to it.

the orifice of the hydropower plant increases with increase in water consumption and the speed of flow of turbine blades.. It is determined by the formula:

$$
N=\eta_{m} \cdot \eta_{e 己} \cdot \rho \cdot g \cdot Q \cdot H_{n i d} .
$$

where $\rho$ is the density of water, $\mathrm{kg} / \mathrm{m}^{3}$

$g$ - acceleration of gravity, $\mathrm{m} / \mathrm{s}^{2}$

$Q$ - water consumption through the turbine, $\mathrm{m}^{3} / \mathrm{s}$, 
$H_{\text {nid }}$ - water head supplied to the turbine, m,

$\eta_{m}$ - Hydraulic turbine efficiency,

$\eta_{e z}$ - Power Generator Efficiency.

Supplied to the turbine head $H_{n i d}$ is equal to the difference in levels in the upper and lower reservoir (buffer), excluding hydraulic losses.

The hydropower plant project is being developed on the basis of topographic-geodetic and engineering-geological studies. Long-term observations of the hydrological regime of the river are used: costs, levels, ice regime. The pressure at the hydroelectric unit $\mathrm{H}_{\mathrm{HPP}}$ is equal to the difference in the water levels of the upper and lower buffers. At $\mathrm{H}_{\text {HPP }}<25 \mathrm{~m}$ the plant is referred to as low pressure. The head of the unit (hydraulic unit) is the difference of the specific potential energies at the inlet and outlet of the hydro turbine and is determined from the formula:

$$
H_{\text {бл }}=H_{\text {ГЕС }}-\Delta h_{\text {кін }},
$$

where $\Delta h_{\text {кін }}$ - loss of kinetic energy in water and drainage structures of the dam. According to hydraulics, these losses are proportional to the square of the water velocity (and therefore the square of the consumption rate). At low-pressure dams with $\mathrm{H}_{\mathrm{HPP}}=6 \ldots 8 \mathrm{~m}$ the head pressure of the block can be reduced by $10 \ldots 15 \%$ only due to the lattices that hold the garbage.

The water consumption in the reservoir (upper buffer) depend not only on the flow through the dam, but also on the water intake for the needs of water supply, precipitation, evaporation, filtration, ice formation. The consumption in the lower buffer depends on the consumption through the turbines, blank discharges, filtration.

\subsubsection{Hydraulic turbines}

The conversion of the potential energy of water of a hydro power station into mechanical energy transmitted to electric generators occurs in hydraulic turbines. While turbine operating energy losses occur. Hydraulic losses are associated with viscous friction and vortex formation as water moves through the turbine. Volumetric losses are caused by the flow of some volume of fluid through the intervals between the turbine blades and the walls of the stator unit. Mechanical losses are due to friction in the 
bearings. The total power loss is taken into account by the efficiency of the turbine $\eta_{m}$. Modern turbines are characterized by values of $\eta_{m}=0,85 \ldots 0,9$.

For low pressure, including small, hydropower plants turbines of a propeller type with a horizontal shaft are optimal. In Fig. 2.1. a hydroelectric unit for microHPP with a capacity of 7 to $50 \mathrm{~kW}$, head from 3 to $10 \mathrm{~m}$, water consumption - from 0.3 to $0.9 \mathrm{~m}^{3} / \mathrm{s}$ is schematically presented. Hydroelectric units of this type are placed in the body of the dam without recess, which reduces the cost of construction of hydropower plants. Dimensions of horizontal turbines are smaller than vertical.

With the increase in the pressure on the dam, the advantages are the hydraulic units with a vertical axis: rotary blade axial, diagonal, radial axial. At very high pressures (hundreds of meters) bucket turbines with a horizontal axis are used.

Capsule reversible hydro-aggregates for hydro-accumulating and tidal power plants are being distributed. In these units, the impeller of the hydraulic machine is located outside the capsule (gondola), and the electric machine is inside it. When the gondola is being flown with the water flow, the unit operates in turbine mode, the electric machine generates current in generator mode. If it is necessary to pump water, the current is supplied to the unit from the energy system, the electric machine operates in the mode of electric motors and rotates the shaft in the opposite direction. In this case, the impeller functions as a pump. For the turbine mode of operation of such units we have values of efficiency at the level of $85 \%$, for the pump mode - at the level of $75 \%$.

\subsubsection{The impact of hydroelectric power plant operation on the energy system}

An important advantage of hydropower is the high agility of the hydropower units - they can be started at full capacity in a very short time (40...50 seconds). Thermal and nuclear power plants do not have this capability. According to the law of thermodynamics, the efficiency of thermodynamic cycles increases with the increase of the parameters of the coolant - pressure and temperature.

Transition modes (power ups and downs) also pass at low speeds and vary in small ranges. However, energy consumption can vary widely. 
At night time there is a "failure" of loading, in the daytime and in the evening - "peaks". If only the thermal and nuclear power plants were to be supplied, they would waste fuel during the load failure.

The uneven schedule causes the thermal power plants to stop at night. The process of starting the boilers and turbines of the TPP is the most difficult in their operation. The greatest danger is caused by the start-ups of the units from the non-cooled state, since the individual elements of the equipment, cooling at different speeds, have different temperatures. There are thermal stresses, changes in the gaps in the connected nodes and parts. Therefore, start-ups and stops of steam turbine units are characterized by the highest accidence and high wear of the equipment. Downtime for boilers and turbines in emergency repairs, overhaul and overhaul costs increase. As a result, the cost of energy at the TPP increases.

Hydraulic power plants are ideal for removing peaks. For this reason, hydroelectric power plants are designed and built at a capacity exceeding the average drainage capacity. They work mainly in the variable part of the load schedule, accumulating water in the upper buffer during periods of load failure and triggering it during the peak.

\subsubsection{Pumped hydroelectric energy storages}

Increasingly, Pumped hydroelectric energy storages (PHES) that operate in alternating mode are increasingly used in the world energy: energy accumulation (charge) is replaced by energy recovery (discharge).

A charge is the lifting of water by hydromachines from the lower to the upper reservoir (at night, on weekends and holidays when there is a load failure in the energy system). This generates excess capacity of thermal and nuclear power plants. Discharge - in hours of maximum load or in case of accidents at other power plants; the potential energy of the raised water is converted into electrical energy in the turbine and generator. Thus, when charging, the PHES operates as a pumping station and at discharge - as a conventional HPP. Having spent four units of electricity on the charge, we return three units at discharge. The power consumed by the charge when the PHES is operating in pumping mode is determined by the formula:

$$
N_{H}=\eta_{H} \cdot \rho \cdot g \cdot Q \cdot h_{H} / 1000, \kappa B m,
$$

where $h_{H}$ is the given head (sum of static head and loss), 
$\eta_{H}$ - pump mode efficiency.

In the plain part of Ukraine, the head of possible PHES do not exceed $120 \mathrm{~m}$, in the Carpathians, the construction of PHES with a head of $400 \mathrm{~m}$ is possible.

Semi-peak PHES are also being developed, designed to operate in a $10 \ldots 12$ hour zone. Semi-peak PHES require the construction of larger storage tanks and higher pumping capacity comparing to turbines. Powerful pumps have to be installed in addition to reversible hydraulic units.

\subsubsection{Tidal power plants}

The attraction of the moon and the sun generate a tidal wave in the oceans. The height of this wave is maximum when the Earth, the Moon and the Sun are on the same line, and it is minimum when the directions to the Moon and the Sun make a right angle. As a result of the daily rotation of the Earth, the wave is accumulated on the shores of the continents. The amplitude of the tidal fluctuations of the level on the shores depends on the bottom relief and the shape of the shoreline. For example, the maximum height of tidal fluctuations in the Bay of Fundy (Atlantic coast of Canada) is $19.6 \mathrm{~m}$.

\subsubsection{Wave Energy}

From the energy point of view, sea waves are a concentrated form of wind energy. Winds that blow over the ocean are wreaking waves, the strength of which depends on the speed of the wind and the length of the run. In the waves water particles make circular motions. The wave height is equal to the diameter of the circular orbit of a particle on the surface.

The mechanical energy of the wave is proportional to the length and the square of the height. The energy of a wave of six meters in height exceeds $100 \mathrm{~kW}$ per 1 linear meter of wave front. Average for ocean waves energy is estimated at $50 \mathrm{~kW} / \mathrm{m}$. Experts have estimated that taking into account the inevitable losses of wave energy use on the coast of England would give $120 \mathrm{GW}$, which is more than the total power of the country's power plants. The total wave power of the oceans is estimated at $2700 \mathrm{GW}$. 


\subsection{Basic indicators of hydrological calculations}

The drainage rate is the ratio of the average long-term value of river costs (over $40 \ldots 50$ years) to the intake area.

The drainage module expresses the rate of runoff in specific units, i.e the ratio of the amount of water (in 1/s) flowing from one square kilometer of the intake area:

$$
M_{0}=\frac{1000 \cdot Q_{0}}{F}, \pi / c \text { with } 1 \kappa M^{2}
$$
$\mathrm{km}^{2}$.

where $Q_{0}$ - average long-term costs, $\mathrm{m}^{3} / \mathrm{s} ; F$ - water intake area in

Stock volume:

$$
W=Q_{0} \cdot T,
$$

where $T$ is the number of seconds in the period over which the drainage is measured.

Annual height of water (drainage layer):

$$
h_{0}=\frac{W_{0} \cdot 10^{3}}{F \cdot 10^{12}}=M_{0} T .
$$

Modular coefficient is the ratio of drainage value to average multiyear drainage value over the same periods:

$$
k_{i}=M_{i} / M_{0}=W_{i} / W_{0} .
$$

It can be annual, seasonal, monthly, maximum and minimum.

Drainage coefficient is the ratio of the height of the drainage layer $(h)$ to the amount of precipitation $(\chi)$, which fell in the drainage basin:

$$
\eta=h / \chi
$$

The calculation of the percentage of availability of annual drainage for each year of observations is calculated by the formula:

$$
P=\frac{m-0,5}{n} \cdot 100, \%
$$

where $P$ is the percentage of availability of annual drainage for each year of observations;

$m$ is the ordinal number of a member of a row when positioning them in the direction of decrease; 
$n$-is the number of all members in a row.

To determine the ordinates of the availability curve, you need to know three numerical parameters: drainage rate $\left(Y_{0}\right)$; the coefficient of variation $\left(c_{v}\right)$ is the ratio of the root-mean-square deviation to the arithmetic mean of the series $Y ; c_{s}$ - asymmetry coefficient, which characterizes the amplitude of fluctuations in drainage values in a number of observations:

$$
c_{v}=\sqrt{\frac{\sum(k-1)^{2}}{n-1}},
$$

where $k=Y_{i} / Y_{0}-$ modular coefficient;

$$
c_{s}=\frac{\sum(k-1)^{3}}{(n-1) c_{v}^{3}} .
$$

In short-term observations, the following value is assumed: $c_{s}=2 c_{v}$.

To move from table values to others, use the ratio:

$$
k=\Phi \cdot c_{v}+1,
$$

where $\Phi$ is the deviation of the ordinates of the availability curve (Annex 1); $c_{v}$ - calculated coefficient of variation for a given series.

In the absence of these observations of the drainage or their short duration (less than 10 years), the value of the coefficient of variation is determined by the approximate expression:

$$
c_{v}=0.723-0.213 \lg M_{0}-0.063 \lg (F+1),
$$

where $M_{0}$ - drainage rate; $F$ - intake area.

The intra-annual drainage distribution depends on climatic conditions and is given in annex 2 for the country's macro-regions. It serves while calculations when there is no information for a specific object. In annex 3 the approximate magnitude of the specific maximum consumption of spring floods is given. To obtain the estimated value, the table data must be multiplied by the intake square. Maximum summer and autumn rainfall floods are much lower than spring ones.

\subsection{The calculation of low power hydropower plant}

To carry out the calculations we set the following symbols: set by marks natural water levels $-\mathrm{V}(\mathrm{m})$; flow length $-\mathrm{L}_{\mathrm{j}}(\mathrm{km})$; water consumption $-Q_{j}\left(\mathrm{~m}^{3} / \mathrm{s}\right) ; j$ is the number of the gate $(j=1, \ldots, 10)$, where 
the numbering of the objects goes from top to bottom according to the river flow; restriction on the maximum raising of the water level $-\mathrm{Z}_{\max } ; Д_{1}(\mathrm{~m})-$ impeller diameter; $\mathrm{h}_{\text {доп }}(\mathrm{m})$ - minimum permissible depth of flow for installation of free-flow units for set values $Д_{1}$ and $V_{p}(\mathrm{~m} / \mathrm{s})-$ flow velocity; $\mathrm{L}_{\min }(\mathrm{m})$ is the minimum permissible distance between freeflowing units, placed in a raw along the river.

The calculation of the main categories of winter non-freezing potential of the flow is done for hydrological conditions that correspond to an availability of $50 \%$. Flow consumption in each gate is considered constant throughout the year, $\mathrm{Q}_{\mathrm{i}}=$ const.

Only HPP that do not alter the natural hydrological flow regime are considered. For these hydropower plants, a constant time level of water in the reservoir or upper buffer (UB) is assumed to be any hydropower station $\left(Z_{B D}\right)$ and equal to the NSL (m) - the normal supporting level, i.e

$$
Z_{B Б}(t)=H \Pi P=\text { const }
$$

Accordingly, all natural flow consumption is skipped without redistribution in time to the lower buffer (LB) of the HPP:

$$
Q_{H b}(t)=Q(t) \text {. }
$$

The installed power of the HPP dams $N_{в c m 1}^{\Gamma E C}(\mathrm{~kW})$ is determined in each 1st calculated gate of the HPP by the formula:

$$
N_{\text {вст1 }}^{\Gamma E C}=9,81 \cdot \eta_{\Gamma E C} \cdot Q_{\text {розр }} \cdot H a_{i}=K_{n} \cdot Q_{\text {розр }} \cdot H a_{i}
$$

where $\eta_{\Gamma E C}(0 . \mathrm{e})-.\mathrm{HPP}$ efficiency, and $\mathrm{K}_{\mathrm{n}}=9.81 \mathrm{n}_{\mathrm{HPP}}-$ power coefficient;

It is accepted that

$$
Q_{\text {розр }}=0,6 \cdot Q_{i}
$$

where $Q_{i}\left(\mathrm{~m}^{3} / \mathrm{s}\right)$ is the flow consumption in the $\mathrm{i}$-th calculated gate; $H a_{i}(\mathrm{~m})$ is the head of the HPP unit, defined by the formula:

$$
H a_{i}=H \Pi P_{i}-Z_{H Б i} \text {, }
$$


where $H \Pi P_{i}(\mathrm{~m})$ is the normal supporting level of the upper buffer (UB) of the HPP in the 1st gate.

$Z_{H b i}(\mathrm{~m})$ is the estimated level of the lower buffer (LB) of the HPP in the 1st gate, which is differently determined depending on the type of cascade and restrictions on the level of the LB.

For the lowest one down the flow (HPP1):

$$
Z_{H Б i}=Z^{\min \partial o n}=102 \mu=\text { const. }
$$

For a closed cascade of the HPP dams "down the flow" (except HPP at the mouth of the flow):

$$
Z_{H Б i}=H \Pi Y_{i+1} .
$$

For the open cascade of the HPP dams "down the flow":

$$
Z_{H Б i}=V_{i}+\Delta Z_{H Б i}=V_{i}+0.256 \cdot Q_{p о з},
$$

where $V_{i}(m)$ - the mark of the water level in the i-th gate

The number of hours of use of the HPP installed capacity "down the flow" $-\mathrm{h}$ (hours) is taken to be equal to 3000 hours.

The 1st supply of hydroelectric power from HPP is considered efficient (expedient) if the distance from the consumer to the flow or location of the HPP $\left(\mathrm{L}_{1}\right)$ is less than the economic radius $\left(\mathrm{R}_{1}\right)$, i.e $\mathrm{L}_{1}<\mathrm{R}_{1}$.

The calculation of the water-energy cadastre of the flow is carried out using the method of "linear accounting".

The length of the flow between the $j$ and $j-1$, ie $l_{1, j-1}$ is determined by the formula:

$$
I_{1, j-1}=L_{j}-I_{j-1}, M .
$$

Head of the same section:

$$
H_{j, j-1}=V_{j-1}-V_{j}, M .
$$

Average cost per division:

$$
Q_{j, j-1}=0.5 \cdot\left(Q_{j}+Q_{j-1}\right), M^{3} / c .
$$

Potential flow capacity at the same division:

$$
N_{j, j-1}=9.81 \cdot H_{j, j-1}+Q_{j, j-1}, \kappa B m .
$$


Specific flow power:

$$
i N_{j, j-1}=N_{j, j-1} / I_{j, j-1}, \kappa B m / \kappa M .
$$

Gross flow potential

$$
N_{\text {вал }}=\sum_{j=2}^{10} N_{j, j-1} .
$$

\section{Wind energy}

\subsection{Wind energy resources}

Winds are the currents of atmospheric air generated by the uneven heating of the Earth's surface by solar radiation. Wind energy has been used by humankind since time immemorial, mostly in sailing shipping and windmills. For example, in the Netherlands, windmills have been pumping water from polders, land bonings lying below sea level, for more than 500 years. Multi-bladed windmills in the United States have been widely used to pump water from wells; in the 30s of the twentieth century, there were more than 6 million units.

The European wind farms are located mainly on the coasts of the Baltic, North Seas and Atlantic Ocean. Offshore wind turbines are popular when installed away from the shore, problems of land alienation for construction are eliminated, and noise loads are reduced.

According to the Interdepartamental Scientific and Technical Center of Wind Energy of the National Academy of Sciences of Ukraine, the territory of our country has considerable wind energy resources, which are estimated at $30 \mathrm{TWh} / \mathrm{y}$.

Today, 13 wind power plants have been built in Ukraine: 10 in the Autonomous Republic of Crimea (of which only 6 operate), one wind farm in the Donetsk and Mykolaiv regions, as well as one plant near Truskavets in the Carpathians.

Also today there is a number of opinions against the development of wind power. Windmills and power lines are thought to damage the landscape. You can hear noise, possible infrasound vibrations, possible interference with television, at a distance up to a kilometer. Therefore, in 
Western Europe, wind farms are being built in shallow water, at some distance from the seashore. Birds can suffer from windmill blades.

\subsection{Designs of wind motors and wind power plants}

A wind stream passing through a square Fflowing between the blades of the wind motor has energy

$$
E=m \cdot w^{2} / 2 \text { Дж, }
$$

where $w$ - wind speed, $\mathrm{m} / \mathrm{s}$,

$m$ - mass of air.

Per second through the area $F$ mass $m=\rho \cdot w \cdot F \mathrm{~kg} / \mathrm{s}$ flows, where $\rho=p / R T$ - air density, $\mathrm{kg} / \mathrm{m}, p$ - atmospheric pressure, $\mathrm{Pa}, R=287 \mathrm{~J} /(\mathrm{kg} \cdot \mathrm{K})-$ gas constant, $T$ - absolute temperature, K. For a blade wind wheel, the square $F$ is determined through the length of the blade $L: F=\pi L^{2}$. Accordingly, the electrical power $N$ increased by the wind turbine, is determined by the formula

$$
N=\eta_{B} \cdot \eta_{e z} \cdot \rho \cdot \pi \cdot L^{2} \cdot w^{2}, B m,
$$

where $\eta_{\text {in- }}$ Wind turbine efficiency,

$\eta_{e r}$ - Electric efficiency of wind generator and transducer (within 0.70...0.85).

It has been experimentally established that windmills with a vertical rotor axis are less efficient than wind wheels with a horizontal axis and with two or three blades. Modern blades are made of fiberglass, designed using hydrodynamic methods taking into account a three-dimensional wrap. The width (chord) of the blade is reduced to its end, this is done to reduce noise. Noise level near full-capacity wind turbine does not exceed $100 \mathrm{~dB}$. The length of the blade reaches $50 \mathrm{~m}$, respectively, the height of the mast tower exceeds $50 \mathrm{~m}$. The efficiency of modern windmills $\eta_{b}$ is at the level of $25 \ldots 33 \%$. The wind turbine operation is calculated at a wind speed of 3 to $25 \mathrm{~m} / \mathrm{s}$, the maximum estimated wind speed before the rotor is destroyed is $60 \mathrm{~m} / \mathrm{s}$.

\subsection{Operation of wind power plant for the energy system}

Wind speed varies throughout the day and is usually seasonal. Accordingly, the power of the energy produced by wind power plants changes, and excesses and failures of its share in the load of the energy 
system occur. Therefore, in order to maintain the frequency of the current, it is necessary to have a reserve capacity in the power system. The simplest solution is working together on the energy system of wind and hydraulic power stations, including HPP. Excess energy produced by wind farms during hours of minimum power consumption can be accumulated by pumping water into the pool above. It can be used by pumping compressed air into underground reservoirs or by producing hydrogen fuel by electrolysis of water.

In Ukraine, the production of wind power plants was established at Dnipropetrovsk "Southern Machine-Building Factory". Ukrainian power machinery engineering has sufficient experience for solving mechanical and electromechanical problems of wind turbine development and production. However, there are concerns about freezing the rotor in winter, especially in regions where cold air is adjacent to the non-freezing sea. According to literary data, in Denmark and northern Germany, operating wind turbines do not freeze in winter, as vibrations of fiberglass blades shake off stuck pieces of ice. However, when the wind turbine is stopped, the icing of rotor can cause destruction.

\subsection{The calculation of wind power plant}

\subsubsection{Average monthly and average annual wind speed}

Data on average monthly and annual wind speeds are presented for selected plants in Table 1 .

Table 1. presents wind speeds for the height of the weather vane below the estimated wind turbine. Therefore, for further calculation we will need a correction coefficient of altitude $k_{h}$ and wind speed at a height of $60 \mathrm{~m} U$, which are determined by the formulas:

$$
\begin{aligned}
k_{h} & =\left(\frac{H}{h_{\phi}}\right)^{m}, \\
U_{H} & =U_{\phi} \cdot k_{h} .
\end{aligned}
$$

where $k_{h}$ is the height correction coefficient (Hellmann exponent);

$H$ - the height at which you want to know the wind speed $U$;

$h_{\phi}$ - weather vane height; 
$\mathrm{m}=0,14$ - indicator of degree function, varying depending on wind speed and meteorological conditions;

$U_{H}$ - wind speeds at height $\mathrm{H}=60 \mathrm{~m}$;

$U_{\phi}$ - wind speed at the height of the weather vane.

Table 1

Average monthly and average annual wind speed

\begin{tabular}{|c|c|c|c|c|c|c|c|c|c|c|c|c|c|c|c|}
\hline$\frac{\overrightarrow{\tilde{E}}}{\underline{\Omega}}$ & 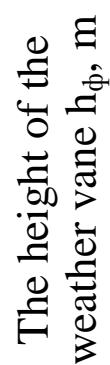 & $\neg$ & $=$ & 目 & $\geq$ & $>$ & 5 & $\stackrel{\nabla}{>}$ & $\stackrel{\Xi}{>}$ & $\underset{\Xi}{ }$ & $x$ & $\bar{x}$ & $\bar{\nabla}$ & $\frac{\theta}{0}$ & 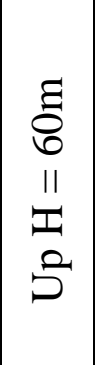 \\
\hline 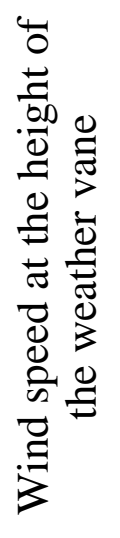 & 16 & 7,5 & 6,5 & 5,9 & 5,0 & 4,7 & 4,9 & 5,1 & 5,7 & 6,2 & 6,8 & 6,8 & . & 6,1 & \\
\hline 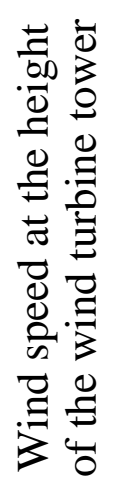 & & 9,0 & 7,8 & 7,1 & 6,0 & 5,7 & 5,9 & 6,1 & 6,9 & 7,5 & 8,2 & 8,2 & 9,1 & - & 7,3 \\
\hline
\end{tabular}




\subsubsection{The repeatability of wind directions and calms}

Repeatability of wind and calm directions is presented in Table 2.

Table 2

The repeatability of wind directions and calms

\begin{tabular}{|c|c|c|c|c|c|c|c|c|c|c|}
\hline$\frac{\vec{\Xi}}{\tilde{a}}$ & 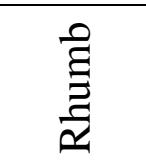 & $\begin{array}{l}\bar{E} \\
\bar{Z}\end{array}$ & 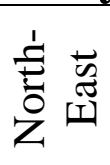 & $\begin{array}{l}\overrightarrow{\mathscr{g}} \\
\text { I }\end{array}$ & 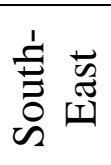 & $\begin{array}{l}\text { 音 } \\
\text { in }\end{array}$ & 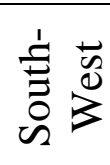 & $\vec{z}_{\overrightarrow{3}}^{\vec{s}}$ & 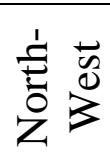 & $\frac{\Xi}{\tilde{U}}$ \\
\hline \multirow{2}{*}{ Baltiysk } & $\Delta \Phi, \%$ & 11 & 8 & 12 & 11 & 14 & 16 & 14 & 14 & \multirow[t]{2}{*}{3} \\
\hline & K & $10 \mathrm{~b}$ & $9 b$ & $9 b$ & $9 b$ & $9 b$ & $10 \mathrm{~b}$ & $10 \mathrm{~b}$ & $10 \mathrm{~b}$ & \\
\hline
\end{tabular}

The data presented in table 2.2, allow you to determine the class of openness weather stations. The general openness class of the station $K_{\text {за }}$ is determined by the formula:

$$
K_{\text {заг }}=\sum_{1}^{8} K_{\text {табл }} \cdot \Delta \Phi
$$

where $K_{\text {табл }}$ is a table class of openness for each rhumb of the wind direction (in this case $K_{\text {табл }}$ is the same for all directions);

$\Delta \Phi-$ table value of the wind frequency of a given rhumb per year, $\%$.

It should be borne in mind that $\sum_{1}^{8} \Delta \Phi=100 \%$, excluding the calm. However, many, and often most, weather stations are not representative. Therefore, in wind energy calculations, the data of all weather stations are processed.

Since wind energy resources are determined for open-area conditions, which may involve the construction of wind turbines and wind farms, a correction coefficient of openness $\hat{E}_{\hat{\imath}}$ is introduced, which can be determined by the formula:

$$
K_{o}=\sum \frac{K_{\max }}{K_{\text {табл }}} \cdot \Delta \Phi
$$

where $K_{\max }$ is the maximum openness coefficient accepted:

$K_{\text {max }}=9$ - for areas situated on the coast of the sea or ocean, and for islands;

$K_{\max }=8-$ for coastal areas 
$K_{\max }=7$ - for areas farther from the shoreline.

If the maximum value of the table coefficient of openness is $K_{\text {табл.max }}$ greater than the above values of $K_{\text {макс }}$, then it should be accepted: $K_{\max }=K_{\text {табл } \max }$.

Station openness class $C_{\text {total }}=9.55$.

\subsubsection{The probability of wind speed by gradation}

Probability of wind speed by gradation is the most important characteristic of the wind cadastre. This distribution characterizes the frequency or probability of the values of the set wind speeds (gradation) in\% of the total number of cases over the considered period of time (month, year).

The probability of wind speed on gradients for all stations is presented in Table 3.

Table 4. presents the differential repetition of the mean induced wind speed by months in gradations in $\%$ of the total number of cases. The values of the differential frequency of wind speed by months are determined by the known values of the average monthly wind speed calculated in table 1., for the first type of velocity distribution (open sea coast).

Table 3

\section{The probability of wind speed by gradation Baltiysk (\% of total cases)}

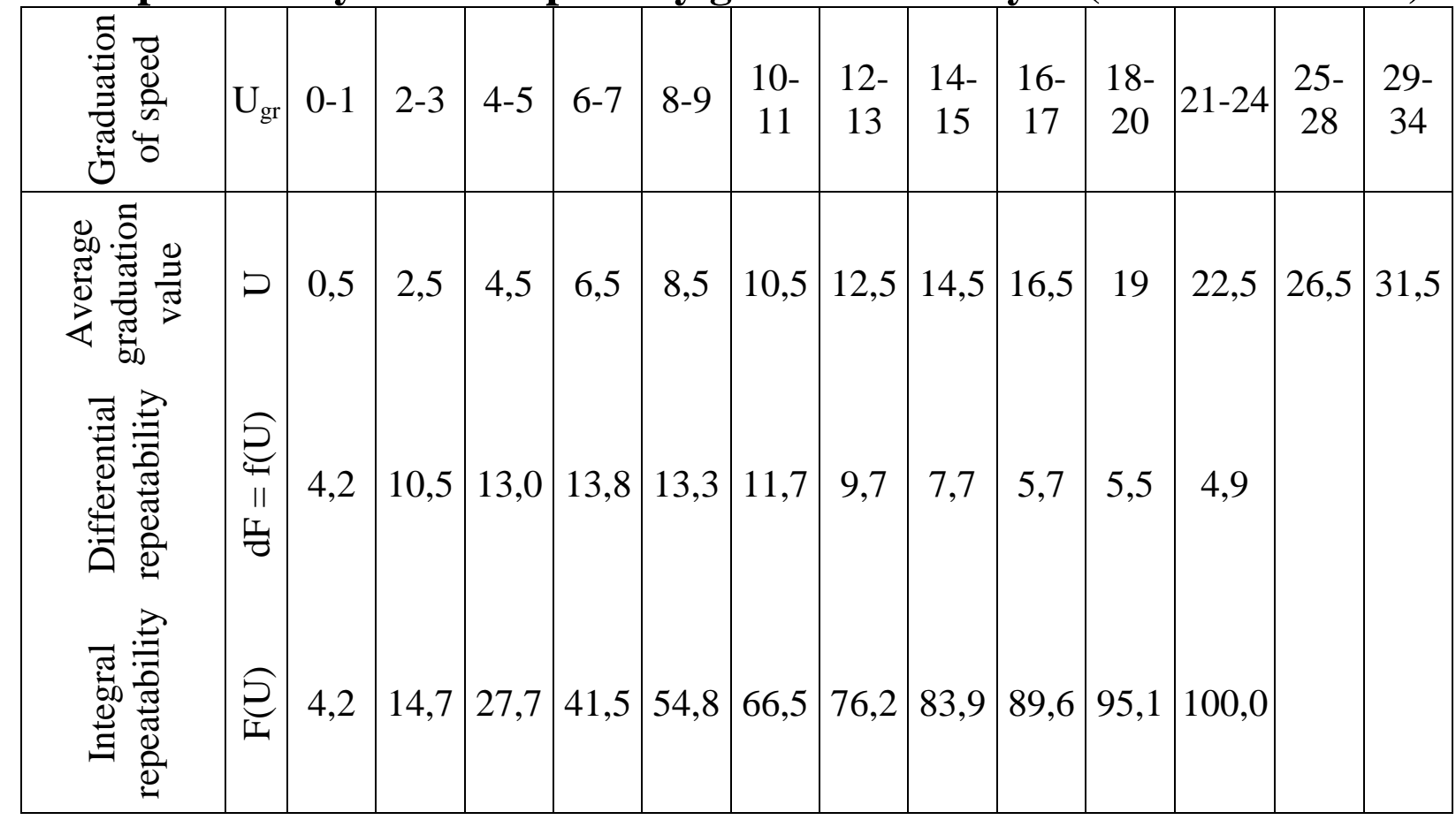


Table 4

The differential repetition of the wind speed by months in gradations in \% of the total number of cases

\begin{tabular}{|c|c|c|c|c|c|c|c|c|c|c|c|c|}
\hline $\begin{array}{c}\text { Month } \\
\mathrm{U}_{\text {pr }}, \mathrm{m} / \mathrm{s}\end{array}$ & I & II & III & IV & V & VI & VII & VIII & IX & X & XI & XII \\
\hline 0,5 & 0,8 & 1,1 & 1,3 & 1,6 & 1,8 & 1,7 & 1,6 & 1,3 & 1,2 & 1 & 1 & 0,8 \\
1 & 4,15 & 5,1 & 5,9 & 7,5 & 8,1 & 7,7 & 7,3 & 6,2 & 5,4 & 4,7 & 4,8 & 4 \\
2 & 5,7 & 7 & 8,1 & 10,1 & 10,8 & 10,3 & 9,8 & 8,4 & 7,4 & 6,5 & 6,6 & 5,6 \\
3 & 6,75 & 8,2 & 9,3 & 11,4 & 12,1 & 11,6 & 11,1 & 9,7 & 8,6 & 7,7 & 7,8 & 6,6 \\
4 & 7,35 & 8,8 & 9,9 & 11,7 & 12,3 & 11,9 & 11,5 & 10,2 & 9,2 & 8,3 & 8,4 & 7,2 \\
5 & 7,7 & 9 & 9,9 & 11,2 & 11,6 & 11,3 & 11,1 & 10,1 & 9,4 & 8,5 & 8,6 & 7,5 \\
6 & 7,75 & 8,8 & 9,5 & 10,2 & 10,3 & 10,2 & 10,1 & 9,6 & 9,1 & 8,4 & 8,5 & 7,7 \\
7 & 7,6 & 8,4 & 8,7 & 8,8 & 8,7 & 8,8 & 8,9 & 8,8 & 8,5 & 8,1 & 8,2 & 7,5 \\
8 & 7,3 & 7,7 & 7,8 & 7,3 & 7 & 7,3 & 7,4 & 7,7 & 7,7 & 7,6 & 7,6 & 7,2 \\
9 & 6,8 & 6,9 & 6,7 & 5,9 & 5,4 & 5,7 & 6 & 6,6 & 6,8 & 6,9 & 6,9 & 6,8 \\
10 & 6,2 & 6 & 5,6 & 4,5 & 4 & 4,3 & 4,6 & 5,4 & 5,9 & 6,1 & 6,1 & 6,2 \\
11 & 5,6 & 5,1 & 4,5 & 3,3 & 2,8 & 3,1 & 3,4 & 4,3 & 4,9 & 5,3 & 5,3 & 5,6 \\
12 & 4,9 & 4,2 & 3,6 & 2,3 & 1,9 & 2,2 & 2,5 & 3,4 & 4 & 4,5 & 4,5 & 4,9 \\
13 & 4,25 & 3,4 & 2,7 & 1,6 & 1,3 & 1,5 & 1,7 & 2,5 & 3,2 & 3,8 & 3,7 & 4,3 \\
14 & 3,6 & 2,7 & 2,1 & 1,1 & 0,8 & 1 & 1,2 & 1,9 & 2,5 & 3,1 & 3 & 3,7 \\
15 & 3 & 2,1 & 1,5 & 0,7 & 0,5 & 0,6 & 0,7 & 1,3 & 1,8 & 2,4 & 2,4 & 3,1 \\
16 & 2,45 & 1,6 & 1 & 0,4 & 0,3 & 0,4 & 0,5 & 0,9 & 1,4 & 1,9 & 1,8 & 2,5 \\
17 & 1,95 & 1,2 & 0,7 & 0,2 & 0,2 & 0,2 & 0,3 & 0,6 & 1 & 1,5 & 1,4 & 2,1 \\
18 & 1,55 & 0,9 & 0,5 & 0,1 & 0,1 & 0,1 & 0,2 & 0,4 & 0,7 & 1,1 & 1 & 1,7 \\
19 & 1,2 & 0,6 & 0,3 & 0,1 & - & 0,1 & 0,1 & 0,3 & 0,5 & 0,8 & 0,8 & 1,3 \\
20 & 0,95 & 0,4 & 0,2 & - & - & - & - & 0,2 & 0,3 & 0,6 & 0,5 & 1 \\
21 & 2,45 & 0,8 & 0,2 & - & - & - & - & 0,2 & 0,5 & 1,2 & 1,1 & 2,7 \\
\hline
\end{tabular}

\subsubsection{The type and characteristics of wind power plant}

The wind farm is planned to include wind farms of the Danish NEG MICON company of the NM 1500/64 type with a capacity of $1500 \mathrm{~kW}$. This installation applies to high capacity wind turbines.

Main technical characteristics of MICON NM 1500/64:

- installed (nominal) capacity $-\mathrm{N}_{\text {wind turbines }}=1500 \mathrm{~kW}$;

- wind wheel diameter $-\mathrm{D}=64 \mathrm{~m}$;

- tower height $-\mathrm{H}=60 \mathrm{~m}$ (conical tower);

- area of the air flowing around the wind wheel $-\mathrm{S}=3217 \mathrm{~m}^{2}$;

- minimum wind speed $-\mathrm{u}=4 \mathrm{~m} / \mathrm{s}$;

- nominal wind speed $-\mathrm{u}=16 \mathrm{~m} / \mathrm{s}$;

- maximum wind speed $-\mathrm{u}=25 \mathrm{~m} / \mathrm{s}$;

- the number of blades -3 pcs.

Frequency of wind wheel rotation - of $17 \mathrm{t} / \mathrm{m}$. 
Asynchronous generator with two pairs of poles. Nominal frequency of electric current $50 \mathrm{~Hz}$. Nominal voltage $690 \mathrm{~V}$.

Weight of three blades $-16,5 \mathrm{t}$. Weight of one blade, respectively $-5,5 \mathrm{t}$.

Weight of the hub of a wind wheel of $14 \mathrm{t}$.

Weight of the tower $-83 \mathrm{t}$.

Weight of the gondola with a rotor and a shaft $-55 \mathrm{t}$.

Total weight of the structure: $170 \mathrm{t}$.

\subsubsection{Capaciry return characteristic}

The capacity return characteristic depending on wind speed of this wind turbine «Micon NM 1500/64» is presented in fig. 1.

The characteristics of wind turbines indicate the following characteristic values of wind speed:

$\mathrm{u}_{0}=4 \mathrm{~m} / \mathrm{s}$ - the minimum wind speed at which the wind turbine starts to give capacity;

$u_{p}=16 \mathrm{~m} / \mathrm{s}$ is the estimated wind speed at which the wind turbine power reaches a value equal to its installed capacity;

$\mathrm{u}_{\max }=25 \mathrm{~m} / \mathrm{s}-$ maximum wind speed above which the wind turbine stops automatically.

Below the dependence of wind turbine capacity on wind speed is given (Table 5).

Table 5

Table of dependence of wind turbine capacity on wind speed

\begin{tabular}{|c|c|c|c|c|c|c|c|c|c|c|c|c|c|c|}
\hline $\mathrm{u}$ & $\mathrm{m} / \mathrm{s}$ & 4 & 5 & 6 & 7 & 13,5 & 14 & 15 & 16 & 17 & 17,5 & 25 & 25 & 30 \\
\hline $\mathrm{N}$ & $\mathrm{kW}$ & 0 & 50 & 125 & 250 & 1390 & 1450 & 1490 & 1500 & 1475 & 1450 & 1250 & 0 & 0 \\
\hline
\end{tabular}

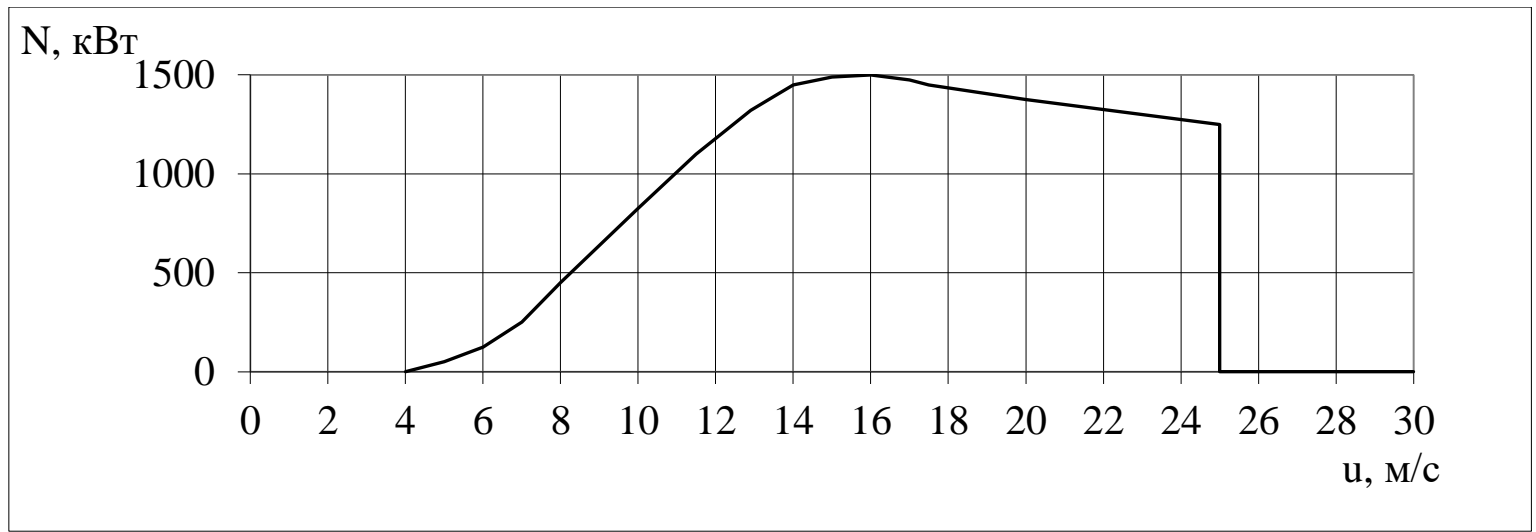

Fig. 1 Capaciry return characteristics of wind turbine MICON NM 1500/64 


\subsection{The description of the device of the wind power plant}

Consider a longitudinal section of the gondola (Fig. 5).

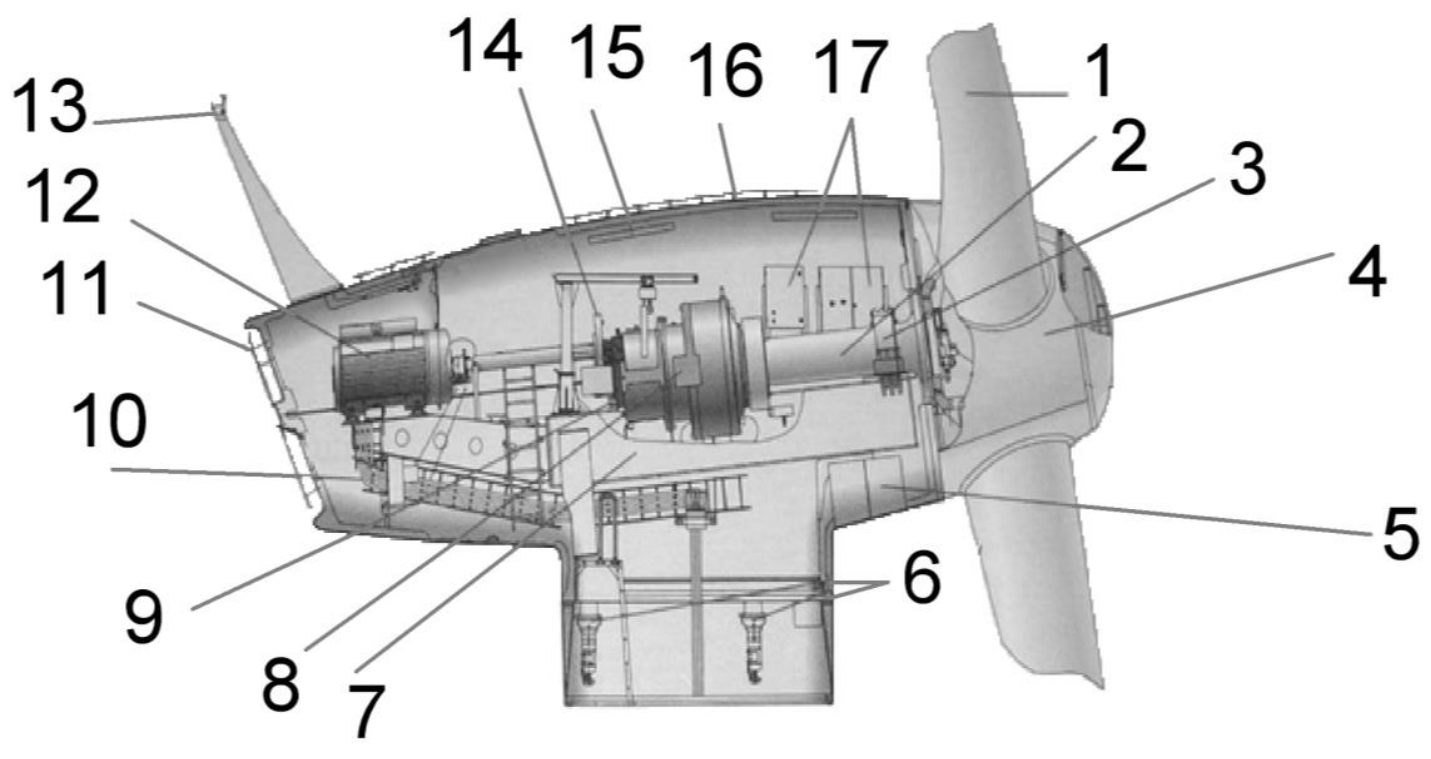

Fig. 2 Longitudinal section of the gondola:

1 - blade; 2 - main shaft; 3 - main bearing; 4 - hub; 5 - air insert; 6 - engine of deviation from the course (rotary device of the gondola); 7 - main construction of the gondola; 8 - reduction gear; 9 - collector rings; 10 - generator cables; 11 - lattice; 12 - generator; 13 - anemometer; 14 - crane (auxiliary equipment); 15 - brake disc; 16 - windows; 17 - remote control.

Wind turbines have three blades made of metal. The place where these blades converge is called the hub (4). In the hub the devices that rotate the blades around its axis are hidden. The hub is rigidly connected to the shaft (2).

The generator rotor is connected to the main shaft. The shaft leans by the main bearing (3) and reduction gear (8) on the main gondola structure (7). A reduction gear is required to convert the frequency of the generator shaft (18) rotation. Reduction gear with gear ratio 1:87,8. Generator (12) operates in a mode with a constant rotation speed of blades and variable speed. An asynchronous generator with two pairs of poles is located in the tail part of the gondola. The generator cables (10) are connected to the collector rings via the collector. The collector rings act as fixed tires.

The working space in the gondola allows two specialists to work freely. 
An anemometer (13) and a wind direction picker are installed at the top of the gondola. As the wind direction changes, the rotary device (6) deploys the rotor downwind. If the speed of the wind exceeds the maximum, then the signal from the anemometer is transmitted to the rotating device of the blade and deploys the blade (stopping the wind wheel).

\subsection{Wind power plant layout}

\subsubsection{The determination of the main technical and economic indicators of wind power plant}

The location of wind turbines in the wind farm on the area is performed in accordance with the wind rose and the area relief of the given map. It should be borne in mind that the distance between wind units should be at least $(5 \div 10)$ diameters of the WT.

This calculation assumes the installation of 16 wind installations at a distance of 7 WT diameters, i.e $450 \mathrm{~m}$ along the prevailing wind direction, and at a distance of 5 WT diameters, i.e $350 \mathrm{~m}$, in a perpendicular direction. Thus, the total capacity of the wind farm will be $24 \mathrm{MW}$.

In order to ensure access to the facilities, it is necessary to provide access paths not less than $6 \mathrm{~m}$ wide and, in addition, a common road leading from the city to the wind plant.

\subsection{Wind power plant and the environment. Environmental factors}

Let us consider the main types of environmental impact of wind farms.

1) Land alienation.

The layout of the wind turbine in the wind farm is shown in the diagram. The area of land seizure is $\mathrm{m}^{2}$. The area of exclusion for individual wind turbines, industrial buildings and structures is $20 \%$ of the total extraction area $\left(\mathrm{km}^{2}\right)$. Traditional economic activities may be conducted in the rest of the WPP territory, with certain restrictions.

2) Emergencies.

During operation of wind turbines there is a danger of destruction and flying away of moving parts of the WT. Depending on the $\mathrm{N}_{\text {wind turbine }}, \mathrm{D}_{\mathrm{WT}}$, 
material, wind force, the danger zone while the destruction of wind turbines may be different:

at $\mathrm{U}<25 \mathrm{~m} / \mathrm{s} \mathrm{L}_{\mathrm{fl}}=9 \mathrm{D}_{\mathrm{wt}}=576 \mathrm{~m}$;

at $\mathrm{U}>25 \mathrm{~m} / \mathrm{s} \mathrm{L} \mathrm{fl}=25 \mathrm{Dwt}=1600 \mathrm{~m}$.

Positive factors for the use of wind energy: reduction of carbon dioxide emissions; slight alienation of land ${ }^{6,7,8,9,10,11,12,13}$.

\section{REFERENCES}

1. Arndt E. Renewable energy sources in Germany: problems and prospects. Innovations + Publicity. 2010. № 2. P. 30-31.

2. Baer G.Ya., Yemets A.I., Stadnichuk N.A., Blume Ya.B., Rakhmetov D.B. Somaclonal Variability As a Source for Creation of New Varieties of Finger Millet (Eleusine coracana (L.) Gaertn) // Cytology and genetics Vol. 41, No 4. Allerton Press. 2007. P. 204-208.

3. Belyakov A.I., Korchevskiy A.A., Spinko V.E. Alternative Perspectives. Academy of Energy. 2010. № 1 (33): February. P. 50-54.

4. Geletukha G., Kudrya S. Non-traditional and renewable energy sources. Ukraine. Green Energy. 2005. № 18. P. 8-10.

5. Zhelykh V.M. Non-traditional energy sources. O.T. Wozniak, Yu.S. Yurkevich, Lviv: Publishing House of Lviv Polytechnic National University. 2009. 83 p.

6. Kudrya S.A., Tuchynsky B. G. Prerequisites, incentives and prospects for the development of wind energy in Europe and in Ukraine. Alternative energy and ecology. 2011. № 8 (100). P. 29-37.

7. Sukhenko Yu.G., Seryogin O.O., Mushtruk M.M., Ryabokon N.V. Innovative technologies of alternative energy supply of food and

\footnotetext{
${ }^{6}$ Arndt E. Renewable energy sources in Germany: problems and prospects. Innovations + Publicity. 2010. № 2. P. 30-31.

${ }^{7}$ Baer G.Ya., Yemets A.I., Stadnichuk N.A., Ya.B. Blume, Rakhmetov D.B. Somaclonal Variability As a Source for Creation of New Varieties of Finger Millet (Eleusine coracana (L.) Gaertn.) //Cytology and genetics Vol. 41, No 4. Allerton Press. 2007. P. 204-208.

${ }^{8}$ Belyakov A.I., Korchevskiy A.A., Spinko V.E. Alternative Perspectives. Academy of Energy. 2010. № 1 (33): February. P. 50-54.

9 G. Geletukha, S. Kudrya. Non-traditional and renewable energy sources. Ukraine. Green Energy. 2005. № 18 P. $8-10$.

${ }^{10}$ Zhelykh V.M. Non-traditional energy sources. O.T. Wozniak, Yu.S. Yurkevich, Lviv: Publishing House of Lviv Polytechnic National University. 2009. 83 p.

${ }^{11}$ Kudrya S.A., Tuchynsky B.G. Prerequisites, incentives and prospects for the development of wind energy in Europe and in Ukraine. Alternative energy and ecology. 2011. № 8 (100). P. 29-37.

${ }^{12}$ Sukhenko Yu.G., Seryogin O.O., Mushtruk M.M., Ryabokon N.V. Innovative technologies of alternative energy supply of food and processing enterprises in examples and problems. Training manual. PC "Comprint", K. 2016.

${ }^{13}$ Sukhenko Yu.G., Seryogin O.O., Sukhenko V.Yu., Ryabokon N.V. Resource-saving technologies in food and processing industries. Textbook. K. 2016.
} 
processing enterprises in examples and problems. Training manual. PC "Comprint", K. 2016.

8. Sukhenko Yu.G., Seryogin O.O., Sukhenko V.Yu., Ryabokon N.V. Resource-saving technologies in food and processing industries. Textbook. K. 2016.

Information about the author: Kyselov V. B.

Doctor of Technical Sciences, Professor, Director of the Institute of Municipal Administration and Urban Economics of the V. I. Vernadsky Taurida National University 